\title{
Effects of Harvest Times on the Fatty Acids Composition of Rose Hip (Rosa sp.) Seeds
}

\author{
Mehmet Güneş $^{1 *}$, Ümit Dölek ${ }^{2}$, Mahfuz Elmastaş ${ }^{3}$, Fatma Karagöz ${ }^{1}$ \\ ${ }^{1}$ Department of Horticulture, Agricultural Faculty, Gaziosmanpaşa University, 60240 Tokat, Turkey \\ ${ }^{2}$ Gökhöyük Vocational and Technical Anatolian High School, 05100 Amasya, Turkey \\ ${ }^{3}$ Department of Chemistry, Art and Science Faculty, Gaziosmanpaşa University, 60240 Tokat, Turkey
}

\begin{tabular}{l} 
A R T I C L E I N F O \\
Research Article \\
Received 02 November 2016 \\
Accepted 04 February 2017 \\
\hline
\end{tabular}

Keywords:

Fatty acid

Rosa

Unsaturated oil

MUFA

PUFA

${ }^{*}$ Corresponding Author:

E-mail: mehmet.gunes@gop.edu.tr \begin{abstract}
A B S T R A C T
This study was conducted to determine the change of fatty acids ratios of some rose hip species seeds in different harvest times. Seeds of five genotypes belonging to rose hip species (Rosa sp.) were used in the study. The fruits of species were harvested in six different ripening times and analyzed. Total oil analysis was performed for the fifth harvest only, which was determined as the optimal harvest time. As a result; total oil ratio of rose hip seeds varied as 5.22 and $6.62 \mathrm{~g} / 100 \mathrm{~g}$ respectively for accessions of Rosa dumalis (MR-12 and MR-15), $6.37 \mathrm{~g} / 100 \mathrm{~g}$ for $R$. canina (MR-26), $5.00 \mathrm{~g} / 100 \mathrm{~g}$ for $R$. dumalis ssp. boissieri (MR-46) and $5.29 \mathrm{~g} / 100 \mathrm{~g}$ for $R$. villosa (MR-84). Eleven fatty acids were determined in rose hip seeds. Among these fatty acids linoleic, oleic, linolenic, palmitic and stearic acids respectively had high ratio. Saturated fatty acids ratio (SFAs) was the highest in $R$. canina (MR-26) and the lowest in $R$. dumalis (MR-12); monounsaturated fatty acids ratio (MUFAs) was the highest in $R$. dumalis (MR-12) and the lowest in $R$. dumalis ssp. boissieri (MR-46); polyunsaturated fatty acids ratio (PUFAs) was the highest in $R$. dumalis ssp. boissieri (MR-46) and the lowest in $R$. dumalis (MR-12). Mono and polyunsaturated fatty acid contents obtained in this study was high; the change of fatty acid profile in the studied species in relation to harvest time was significant for some species and insignificant for others. A conclusion was reached that it is important to pay attention to qualitative and quantitative properties of seeds when conducting studies about rose hip improvement.
\end{abstract}

\section{Introduction}

The seeds of rose hip constitute $30-40 \%$ of the weight of the fresh fruit. While rose hip fruit flesh is processed for different products, the seed part is most often separated as waste. However, with its fatty acids content and other components, rose hip seeds can be used both in cosmetic industry for different product and in folk medicine. Thus, rose hip seed can be used for skin protection, anti-aging or rejuvenating, anti-wrinkle especially around eyes and mouth, sun and heavy weather protection, healing and thickening of wounded tissue. Also, rose hip seed oil helps with the removal of face stains, decreases pigmentation, prevents the cracking of capillaries and protects from acnes (D’amelioi, 1999).

The total oil content in rose hip seeds can vary from $1.3 \%$ to $11.1 \%$ depending on the geographical region, season and species (Ercisli, 2007; Celik et al., 2010; Sharma et al., 2012; Aptin et al., 2013). Palmitic, stearic, oleic, linoleic, linolenic and arachidic acids are most often encountered in rose hip studies (Celik et al., 2010; Sharma et al., 2012; Aptin et al., 2013; Fofana et al., 2013). Oleic, linoleic and linolenic acid content in rose hip seeds is higher and more balanced comparing to canola, olive and blueberries (Fofana et al., 2013).
Rose hip seed is rich with polyunsaturated fatty acids. Among herbal oil sources it has the highest content of omega- 3 and omega- 6 fatty acids. Besides its effect on cholesterol, omega-3 fatty acid has a positive effect on repairing the nervous system and stopping the abnormal cell growth of some types of cancer. For many years, rose hip seed has been used in folk medicine against different pains, for healing some wounds and against skin diseases. To enrich omega- 3 and omega- 6 content, rose hip seed can be ground and added to food or it can be used for feeding poultry and livestock (Nichita et al., 1981; Macit et al., 2003).

Even though physical and phytochemical properties of many fruit species in different maturity periods were determined and appropriate harvest time or period was established accordingly, these kinds of studies remained limited on the subject of rose hip. The determination of the changes in the fatty acid profile of the rose hip seeds depending on the harvest in different periods is important for using the seeds for different purposes.

Studies related to the fatty acid content of the seeds from a mature rose hip fruit were conducted by Ozcan (2002), Ercisli (2007) and Celik et al. (2010). However, 
there has not yet been any study conducted to determine rose hip seeds fatty acid profile related to ripening or different ripening stages. Therefore, the objective of this study is to determine total oil content of rose hip seeds in different harvest times and to evaluate more effectively an important raw material that is readily processed as a waste and thus to contribute to the economy or industry.

\section{Material and Method}

The seeds of Rosa dumalis (MR-12 (accession number) and MR-15), R. canina (MR-26), R. dumalis ssp. boissieri (MR-46) and $R$. villosa (MR-84) genotypes of rose hip species were used. Rose hip parcel containing advanced selections of different rose hip species was established in the year 2000. The research area is located at $+40^{\circ} 20^{\prime} 1.91^{\prime \prime}$ north latitude and $+36^{\circ} 28^{\prime} 38.44^{\prime \prime}$ east longitude. The soil which the parcel was established has a slightly alkaline. Genotypes were propagated by cuttings, 3 bushes belonging to each genotype were planted on condition that the order distance will be $3 \times 3 \mathrm{~m}$ in the parcel. The parcel was watered with drip irrigation. The plants are regularly pruned in every year in JanuaryFebruary. No special pruning system was applied to the shrubs. The parcel was manured and fertilized. The pesticides were applied in certain periods against pests.

Rose hip fruits were harvested between JulySeptember in 6 different harvest time's relation to the species maturing. Fruit color change was used as a basis for determining the harvest time of the first four harvests, while the softening of the fruit flesh was taken as a basis for the rest two harvests. According to that; the first harvest was done when the fruit color started to change from green to yellow (H-1); the second harvest was done when the color of the fruit became more then $50 \%$ yellow $(\mathrm{H}-2)$; the third harvest was done when the fruit became orange in color (H-3); the fourth harvest was done when the fruit became dark orange or red depending on the species $(\mathrm{H}-4)$; the fifth harvest was done the fruit flesh started to soften in some places (H-5) and the sixth harvest was done when the fruit flesh completely softened (H-6). Total oil analysis was performed for the fifth harvest only, which was determined as the optimal harvest time. The seeds removed from the harvested fruits, dried and kept on $-18^{\circ} \mathrm{C}$ until the analysis time.

To determine the fatty acids in rose hip seeds, $5 \mathrm{~g}$ seeds were weighted and milled from each sample then extracted with $10 \mathrm{~mL}$ of hexane for the period of 24 hours. At the end of this period, the extract was filtered with filter paper and the filtrate was evaporated on $40^{\circ} \mathrm{C}$. The obtained oil was poured in amber colored $5 \mathrm{~mL}$ bottles and was kept on $+4^{\circ} \mathrm{C}$ until the analysis time.

Fixed fatty acids composition was analyzed according to the method summarized by Turkekul et al. (2006). In brief, $30 \mathrm{mg}$ of the oil weighted and dissolved in $3 \mathrm{~mL}$ of hexane, $3 \mathrm{~mL}$ of $1 \mathrm{M} \mathrm{KOH}$ solution (prepared in methanol) was added and the mixture vortexed for 3 minutes. When observed clear separation of phases, 0.5 $\mathrm{mL}$ of upper phase diluted with $1 \mathrm{~mL}$ hexane. Final mixture was analyzed directly with GC-FID Perkin Elmer
Clarus 500 GC-FID instrument (USA) equipped Restek (RTX-2330) (USA) (30m x $0.32 \mu \mathrm{mm}$ ID x $0.25 \mu \mathrm{m}$ film thickness) was used. Helium was used as carrier gas in split mode $(50: 1)$ at $1 \mathrm{~mL} / \mathrm{min}$ flow rate. Detector and injection port temperature were $250^{\circ} \mathrm{C}$. The oven temperature program as follows: Initial temp. $120^{\circ} \mathrm{C}$, hold for $2 \mathrm{~min}$, heated to $180^{\circ} \mathrm{C}$ with $2^{\circ} \mathrm{C} / \mathrm{min}$, hold $0 \mathrm{~min}$ then heated to $200^{\circ} \mathrm{C}$ with $4^{\circ} \mathrm{C} / \mathrm{min}$ hold 3 minutes. Total run time was $40 \mathrm{~min}$. The injection volume was $1 \mu 1$. Standard fatty acids mixture (Supelco 37 Component FAME Mix, 47885-U) was used for determination of fatty acids. The percentages of components calculated based on peak areas using Total Chrom v3.1 software.

The obtained results were subjected to the analysis of variance with three replicates in 0.05 significance according to SPSS 15.0 statistic program and for the comparison of the obtained ratio Duncan multiple range test was used.

\section{Results and Discussion}

The results related to the changes of fatty acid ratios in different rose hip species depending on the harvest are presented on Table 1; while the ratio of some fatty acids with high proportional value and importance from the perspective of human health is presented on Table 2.

Eleven fatty acids were determined in the analyzed rose hip seeds. These fatty acids are palmitic, stearic, oleic, linoleic, linolenic, gama-linolenic, arachidic, cis-11, 14-eicosadienoic, behenic, lignoceric and nervonic acid. Besides the above mentioned first five fatty acids, the ratios of remaining were below $1 \%$ (Table 1 ). Total oil ratio of rose hip seeds was 5.22 and $6.62 \mathrm{~g} / 100 \mathrm{~g}$ respectively for Rosa dumalis (MR-12 and MR-15), 6.37 $\mathrm{g} / 100 \mathrm{~g}$ for $R$. canina (MR-26), $5.00 \mathrm{~g} / 100 \mathrm{~g}$ for $R$. dumalis ssp. boissieri (MR-46) and $5.29 \mathrm{~g} / 100 \mathrm{~g}$ for $R$. villosa (MR-84).

Saturated fatty acids ratio (SFAs) was the highest in $R$. canina (MR-26), and the lowest in R. dumalis (MR-12) (Figure 1). Monounsaturated fatty acids ratio (MUFAs) was the highest in $R$. dumalis (MR-12), and the lowest in $R$. dumalis ssp. boissieri (MR-46) (Figure 2). Polyunsaturated fatty acids ratio (PUFAs) was the highest in $R$. dumalis ssp. boissieri (MR-46), and the lowest in $R$. dumalis (MR-12) (Figure 3). MUFAs ratio increased during ripening, while PUFAs ratio decreased.

The SFAs ratio of the $R$. dumalis (MR-12) was between 5.56-5.71\%, MUFAs ratio was between 37.09$40.31 \%$ and PUFAs ratio was between 54.65-57.31\%. Depending on the harvest, same genotype's oleic acid ratio was between $37.07-40.26 \%$, linoleic acid ratio was between $38.90-43.13 \%$ and linolenic acid ratio was between $13.65-15.33 \%$. When the harvest period is taken into consideration dominant oleic, linoleic and linolenic acids ratio difference was statistically significant, while palmitic and stearic acids ratio difference was not. The SFAs ratio of the $R$. dumalis (MR-15) was between 5.78$6.09 \%$, MUFAs ratio was between 24.88-26.25\% and PUFAs ratio was between 67.64-69.08\%. 
Table 1 Ratios of fatty acids that harvested in the different time in some rose hip species (\%)

\begin{tabular}{|c|c|c|c|c|c|c|c|c|c|c|c|c|c|c|}
\hline \multirow{2}{*}{$\mathrm{H}$} & \multicolumn{14}{|c|}{ Fatty Acid } \\
\hline & PA & SA & OA & LA & ALA & GLA & AA & CEA & BA & LIA & NA & SFA & MUFA & PUFA \\
\hline \multicolumn{15}{|c|}{ Rosa dumalis (MR-12) } \\
\hline $\mathrm{H}-1$ & $3.45^{\mathrm{a}^{*}}$ & $2.05^{\mathrm{a}}$ & $37.07^{\mathrm{c}}$ & $43.13^{\mathrm{a}}$ & $13.65^{\mathrm{c}}$ & $0.52^{\mathrm{a}}$ & $0.02^{\mathrm{abc}}$ & $0.01^{\mathrm{c}}$ & $0.07^{\mathrm{a}}$ & $0.01^{\mathrm{b}}$ & $0.02^{\mathrm{a}}$ & 5.61 & 37.09 & 57.31 \\
\hline H-2 & $3.41^{\mathrm{a}}$ & $2.15^{\mathrm{a}}$ & $38.32^{\mathrm{bc}}$ & $41.56^{\mathrm{b}}$ & $14.03^{b c}$ & $0.40^{\mathrm{bc}}$ & $0.01^{\mathrm{abc}}$ & $0.04^{\mathrm{ab}}$ & $0.01^{\mathrm{c}}$ & $0.04^{\mathrm{a}}$ & $0.03^{\mathrm{a}}$ & 5.62 & 38.35 & 56.02 \\
\hline H-3 & $3.44^{\mathrm{a}}$ & $2.18^{\mathrm{a}}$ & $40.26^{\mathrm{a}}$ & $39.16^{\mathrm{c}}$ & $14.32^{b c}$ & $0.50^{\mathrm{ab}}$ & $0.02^{\mathrm{ab}}$ & $0.01^{\mathrm{c}}$ & $0.03^{\mathrm{bc}}$ & $0.01^{\mathrm{b}}$ & $0.05^{\mathrm{a}}$ & 5.69 & 40.31 & 53.99 \\
\hline $\mathrm{H}-4$ & $3.40^{\mathrm{a}}$ & $2.24^{\mathrm{a}}$ & $39.08^{\mathrm{ab}}$ & $39.83^{\mathrm{c}}$ & $14.75^{\mathrm{ab}}$ & $0.60^{\mathrm{a}}$ & $0.01^{\mathrm{bc}}$ & $0.02^{\mathrm{bc}}$ & $0.04^{\mathrm{ab}}$ & $0.02^{\mathrm{b}}$ & $0.03^{\mathrm{a}}$ & 5.71 & 39.11 & 55.19 \\
\hline H-5 & $3.41^{\mathrm{a}}$ & $2.12^{\mathrm{a}}$ & $39.93^{\mathrm{ab}}$ & $39.33^{\mathrm{c}}$ & $14.59^{\mathrm{ab}}$ & $0.52^{\mathrm{a}}$ & $0.00^{\mathrm{c}}$ & $0.02^{\mathrm{abc}}$ & $0.01^{\mathrm{c}}$ & $0.02^{\mathrm{b}}$ & $0.05^{\mathrm{a}}$ & 5.56 & 39.98 & 54.46 \\
\hline H-6 & $3.41^{\mathrm{a}}$ & $2.20^{\mathrm{a}}$ & $39.65^{\mathrm{ab}}$ & $38.90^{\mathrm{c}}$ & $15.33^{\mathrm{a}}$ & $0.37^{\mathrm{c}}$ & $0.03^{\mathrm{a}}$ & $0.04^{\mathrm{a}}$ & $0.01^{\mathrm{c}}$ & $0.01^{\mathrm{b}}$ & $0.04^{\mathrm{a}}$ & 5.66 & 39.69 & 54.65 \\
\hline \multicolumn{15}{|c|}{ Rosa dumalis (MR-15) } \\
\hline H-1 & $3.53^{\mathrm{a}}$ & $2.47^{\mathrm{b}}$ & $24.85^{\mathrm{b}}$ & $48.36^{\mathrm{a}}$ & $20.02^{\mathrm{a}}$ & $0.68^{\mathrm{ab}}$ & $0.01^{\mathrm{a}}$ & $0.02^{\mathrm{c}}$ & $0.02^{\mathrm{a}}$ & $0.01^{\mathrm{a}}$ & $0.02^{\mathrm{a}}$ & 6.04 & 24.88 & 69.08 \\
\hline $\mathrm{H}-2$ & $3.50^{\mathrm{ab}}$ & $2.50^{\mathrm{b}}$ & $25.34^{\mathrm{ab}}$ & $48.13^{\mathrm{a}}$ & $19.79^{\mathrm{a}}$ & $0.66^{\mathrm{b}}$ & $0.01^{\mathrm{a}}$ & $0.04^{\mathrm{bc}}$ & $0.01^{\mathrm{ab}}$ & $0.01^{\mathrm{a}}$ & $0.02^{\mathrm{a}}$ & 6.03 & 25.36 & 68.61 \\
\hline $\mathrm{H}-3$ & $3.33^{\mathrm{c}}$ & $2.49^{\mathrm{b}}$ & $25.89^{\mathrm{ab}}$ & $47.52^{\mathrm{ab}}$ & $19.96^{\mathrm{a}}$ & $0.69^{\mathrm{ab}}$ & $0.01^{\mathrm{a}}$ & $0.06^{\mathrm{ab}}$ & $0.01^{\mathrm{ab}}$ & $0.01^{\mathrm{a}}$ & $0.03^{\mathrm{a}}$ & 5.85 & 25.91 & 68.23 \\
\hline $\mathrm{H}-4$ & $3.36^{\mathrm{c}}$ & $2.40^{\mathrm{b}}$ & $25.33^{\mathrm{ab}}$ & $47.91^{\mathrm{a}}$ & $20.13^{\mathrm{a}}$ & $0.73^{\mathrm{a}}$ & $0.01^{\mathrm{a}}$ & $0.05^{\mathrm{abc}}$ & $0.00^{c}$ & $0.01^{\mathrm{a}}$ & $0.03^{\mathrm{a}}$ & 5.78 & 25.35 & 68.82 \\
\hline H-5 & $3.40^{\mathrm{bc}}$ & $2.54^{\mathrm{ab}}$ & $25.47^{\mathrm{ab}}$ & $47.72^{\mathrm{ab}}$ & $20.03^{\mathrm{a}}$ & $0.7^{\mathrm{ab}}$ & $0.01^{\mathrm{a}}$ & $0.07^{\mathrm{ab}}$ & $0.01^{\mathrm{c}}$ & $0.01^{\mathrm{a}}$ & $0.03^{\mathrm{a}}$ & 5.97 & 25.5 & 68.52 \\
\hline H-6 & $3.48^{\mathrm{ab}}$ & $2.58^{\mathrm{a}}$ & $26.23^{\mathrm{a}}$ & $47.14^{\mathrm{c}}$ & $19.73^{\mathrm{a}}$ & $0.71^{\mathrm{ab}}$ & $0.01^{\mathrm{a}}$ & $0.09^{\mathrm{a}}$ & $0.01^{\mathrm{c}}$ & $0.01^{\mathrm{a}}$ & $0.02^{\mathrm{a}}$ & 6.09 & 26.25 & 67.64 \\
\hline \multicolumn{15}{|c|}{ Rosa canina (MR-26) } \\
\hline H-1 & $4.40^{\mathrm{a}}$ & $4.02^{\mathrm{a}}$ & $24.93^{\mathrm{d}}$ & $50.29^{\mathrm{a}}$ & $14.71^{\mathrm{ab}}$ & $1.14^{\mathrm{a}}$ & $0.01^{\mathrm{a}}$ & $0.06^{\mathrm{a}}$ & $0.01^{\mathrm{a}}$ & $0.01^{\mathrm{a}}$ & $0.03^{\mathrm{ab}}$ & 8.45 & 24.96 & 66.20 \\
\hline H-2 & $4.09^{\mathrm{b}}$ & $3.61^{\mathrm{cd}}$ & $26.24^{\mathrm{cd}}$ & $50.31^{\mathrm{a}}$ & $14.88^{\mathrm{ab}}$ & $0.73^{b}$ & $0.02^{\mathrm{a}}$ & $0.06^{\mathrm{a}}$ & $0.02^{\mathrm{a}}$ & $0.02^{\mathrm{a}}$ & $0.01^{\mathrm{b}}$ & 7.74 & 26.26 & 65.97 \\
\hline H-3 & $3.86^{\mathrm{c}}$ & $3.58^{\mathrm{d}}$ & $27.69^{\mathrm{bc}}$ & $48.97^{\mathrm{b}}$ & $15.21^{\mathrm{a}}$ & $0.57^{b c}$ & $0.01^{\mathrm{a}}$ & $0.06^{\mathrm{a}}$ & $0.02^{\mathrm{a}}$ & $0.01^{\mathrm{a}}$ & $0.02^{\mathrm{ab}}$ & 7.47 & 27.71 & 64.81 \\
\hline H-4 & $3.82^{\mathrm{c}}$ & $3.74^{\text {bcd }}$ & $29.45^{\mathrm{ab}}$ & $47.49^{\mathrm{c}}$ & $14.83^{\mathrm{ab}}$ & $0.57^{\mathrm{bc}}$ & $0.01^{\mathrm{a}}$ & $0.06^{\mathrm{a}}$ & $0.01^{\mathrm{a}}$ & $0.02^{\mathrm{a}}$ & $0.01^{\mathrm{b}}$ & 7.59 & 29.46 & 62.94 \\
\hline H-5 & $3.89^{c}$ & $3.84^{\mathrm{b}}$ & $28.66^{\mathrm{ab}}$ & $48.19^{\mathrm{bc}}$ & $14.78^{\mathrm{ab}}$ & $0.51^{\mathrm{c}}$ & $0.01^{\mathrm{a}}$ & $0.06^{\mathrm{a}}$ & $0.01^{\mathrm{a}}$ & $0.01^{\mathrm{a}}$ & $0.04^{\mathrm{a}}$ & 7.76 & 28.71 & 63.54 \\
\hline H-6 & $3.79^{c}$ & $3.78^{\mathrm{bc}}$ & $30.57^{\mathrm{a}}$ & $47.16^{c}$ & $14.06^{\mathrm{b}}$ & $0.53^{b c}$ & $0.01^{\mathrm{a}}$ & $0.06^{\mathrm{a}}$ & $0.01^{\mathrm{a}}$ & $0.01^{\mathrm{a}}$ & $0.03^{\mathrm{ab}}$ & 7.59 & 30.60 & 61.81 \\
\hline \multicolumn{15}{|c|}{ R. dumalis ssp. boissieri (MR-46) } \\
\hline $\mathrm{H}-1$ & $3.14^{\mathrm{bc}}$ & $4.19^{\mathrm{a}}$ & $13.12^{\mathrm{a}}$ & $56.45^{\mathrm{ab}}$ & $22.49^{\mathrm{a}}$ & $0.48^{\mathrm{b}}$ & $0.01^{\mathrm{b}}$ & $0.04^{\mathrm{a}}$ & $0.01^{\mathrm{c}}$ & $0.01^{\mathrm{ab}}$ & $0.03^{\mathrm{ab}}$ & 7.36 & 13.15 & 79.46 \\
\hline $\mathrm{H}-2$ & $3.10^{\mathrm{c}}$ & $4.16^{\mathrm{a}}$ & $13.48^{\mathrm{a}}$ & $55.93^{\mathrm{b}}$ & $22.86^{\mathrm{a}}$ & $0.47^{\mathrm{b}}$ & $0.01^{\mathrm{b}}$ & $0.04^{\mathrm{a}}$ & $0.02^{\mathrm{a}}$ & $0.01^{\mathrm{ab}}$ & $0.05^{\mathrm{a}}$ & 7.29 & 13.52 & 79.3 \\
\hline $\mathrm{H}-3$ & $3.24^{\mathrm{ab}}$ & $4.15^{\mathrm{a}}$ & $13.77^{\mathrm{a}}$ & $55.41^{\mathrm{bc}}$ & $22.83^{\mathrm{a}}$ & $0.48^{\mathrm{b}}$ & $0.01^{\mathrm{b}}$ & $0.04^{\mathrm{a}}$ & $0.01^{\mathrm{ab}}$ & $0.01^{\mathrm{ab}}$ & $0.04^{\mathrm{ab}}$ & 7.42 & 13.81 & 78.76 \\
\hline $\mathrm{H}-4$ & $2.90^{\mathrm{d}}$ & $4.27^{\mathrm{a}}$ & $13.31^{\mathrm{a}}$ & $57.31^{\mathrm{a}}$ & $21.66^{\mathrm{a}}$ & $0.47^{\mathrm{b}}$ & $0.01^{\mathrm{b}}$ & $0.04^{\mathrm{a}}$ & $0.01^{\mathrm{ab}}$ & $0.01^{\mathrm{b}}$ & $0.01^{\mathrm{b}}$ & 7.2 & 13.32 & 79.48 \\
\hline $\mathrm{H}-5$ & $3.17^{\mathrm{bc}}$ & $4.53^{\mathrm{a}}$ & $13.29^{\mathrm{a}}$ & $55.94^{\mathrm{b}}$ & $22.05^{\mathrm{a}}$ & $0.76^{\mathrm{a}}$ & $0.08^{\mathrm{a}}$ & $0.04^{\mathrm{a}}$ & $0.01^{\mathrm{b}} \mathrm{c}$ & $0.02^{\mathrm{a}}$ & $0.03^{\mathrm{ab}}$ & 7.8 & 13.32 & 78.79 \\
\hline H-6 & $3.33^{\mathrm{a}}$ & $4.36^{\mathrm{a}}$ & $13.46^{\mathrm{a}}$ & $54.78^{\mathrm{c}}$ & $23.12^{\mathrm{a}}$ & $0.70^{\mathrm{a}}$ & $0.04^{\mathrm{b}}$ & $0.06^{\mathrm{a}}$ & $0.00^{\mathrm{c}}$ & $0.01^{\mathrm{ab}}$ & $0.02^{\mathrm{ab}}$ & 7.74 & 13.48 & 78.66 \\
\hline \multicolumn{15}{|c|}{ Rosa villosa (MR-84) } \\
\hline $\mathrm{H}-1$ & $3.70^{\mathrm{b}}$ & $2.39^{c}$ & $21.13^{\mathrm{b}}$ & $55.24^{\mathrm{a}}$ & $17.14^{\mathrm{b}}$ & $0.28^{\mathrm{c}}$ & $0.01^{\mathrm{b}}$ & $0.05^{\mathrm{a}}$ & $0.02^{\mathrm{a}}$ & $0.01^{\mathrm{ab}}$ & $0.04^{\mathrm{a}}$ & 6.12 & 21.17 & 72.71 \\
\hline H-2 & $3.84^{\mathrm{b}}$ & $2.49^{\mathrm{bc}}$ & $21.37^{\mathrm{b}}$ & $54.7^{\mathrm{a}}$ & $17.18^{\mathrm{b}}$ & $0.31^{\mathrm{bc}}$ & $0.02^{\mathrm{b}}$ & $0.02^{\mathrm{b}}$ & $0.02^{\mathrm{a}}$ & $0.01^{\mathrm{ab}}$ & $0.03^{\mathrm{a}}$ & 6.38 & 21.4 & 72.21 \\
\hline H-3 & $3.85^{\mathrm{b}}$ & $2.43^{\mathrm{bc}}$ & $22.03^{\mathrm{b}}$ & $53.66^{\mathrm{a}}$ & $17.48^{\mathrm{b}}$ & $0.47^{\mathrm{ab}}$ & $0.01^{\mathrm{b}}$ & $0.01^{\mathrm{b}}$ & $0.02^{\mathrm{a}}$ & $0.02^{\mathrm{ab}}$ & $0.03^{\mathrm{a}}$ & 6.32 & 22.06 & 71.62 \\
\hline H-4 & $4.31^{\mathrm{a}}$ & $2.68^{\mathrm{ab}}$ & $22.27^{\mathrm{b}}$ & $53.36^{\mathrm{a}}$ & $16.86^{\mathrm{b}}$ & $0.43^{\mathrm{abc}}$ & $0.01^{\mathrm{b}}$ & $0.02^{\mathrm{b}}$ & $0.02^{\mathrm{a}}$ & $0.02^{\mathrm{ab}}$ & $0.03^{\mathrm{a}}$ & 7.04 & 22.3 & 70.66 \\
\hline H-5 & $3.80^{\mathrm{b}}$ & $2.61^{\mathrm{abc}}$ & $22.08^{\mathrm{b}}$ & $53.07^{\mathrm{a}}$ & $17.75^{\mathrm{b}}$ & $0.58^{\mathrm{a}}$ & $0.01^{\mathrm{b}}$ & $0.02^{\mathrm{b}}$ & $0.02^{\mathrm{a}}$ & $0.03^{\mathrm{a}}$ & $0.03^{\mathrm{a}}$ & 6.47 & 22.1 & 71.41 \\
\hline H-6 & $4.36^{\mathrm{a}}$ & $2.88^{\mathrm{a}}$ & $24.28^{\mathrm{a}}$ & $49.31^{\mathrm{b}}$ & $18.60^{\mathrm{a}}$ & $0.43^{\mathrm{ab}}$ & $0.03^{\mathrm{a}}$ & $0.02^{\mathrm{b}}$ & $0.02^{\mathrm{a}}$ & $0.01^{\mathrm{b}}$ & $0.05^{\mathrm{a}}$ & 7.31 & 24.33 & 68.36 \\
\hline
\end{tabular}

H: Harvest, PA: Palmitic Acid (C16:0), SA: Stearic Acid (C18:0), OA: Oleic Acid (C18:1n9c), LA: Linoleic Acid (C18:2n6c), ALA: Alfa - Linolenic Acid) (C18:3n3), GLA: Gama - Linolenic Acid (C18:3n6), AA: Arachidic Acid (C20:0), CEA: Cis - 11,14 - eicos. Acid (C20:2), BA: Behenic Acid (C22:0), LIA: Lignoceric Acid (C24:0), NA: Nervonic Acid (C24:1), *Difference between the means indicated by different letters in the same column is significant $(\mathrm{P}<0.05)$.

Table 2 Ratios of C18:2 / C18:3 and C18:1 / C18:0 in rose hip species depending on harvest time.

\begin{tabular}{c|cccccc}
\hline H & $\begin{array}{c}\text { Fatty acid LA/LNA } \\
\text { OA/SA }\end{array}$ & $\begin{array}{c}\text { R.dumalis } \\
\text { (MR-12) }\end{array}$ & $\begin{array}{c}\text { R.dumalis } \\
\text { (MR-15) }\end{array}$ & $\begin{array}{c}\text { R.canina } \\
\text { (MR-26) }\end{array}$ & $\begin{array}{c}\text { R.dumalis boissieri } \\
\text { (MR-46) }\end{array}$ & $\begin{array}{c}\text { R.villosa } \\
\text { (MR-84) }\end{array}$ \\
\hline H-1 & C18:2 / C18:3 & $3.16: 1$ & $2.42: 1$ & $3.42: 1$ & $2.51: 1$ & $3.22: 1$ \\
& C18:1 / C18:0 & $18.08: 1$ & $10.06: 1$ & $6.20: 1$ & $3.13: 1$ & $8.84: 1$ \\
H-2 & C18:2 / C18:3 & $2.96: 1$ & $2.43: 1$ & $3.38: 1$ & $2.45: 1$ & $3.18: 1$ \\
& C18:1 / C18:0 & $17.82: 1$ & $10.14: 1$ & $7.27: 1$ & $3.24: 1$ & $8.58: 1$ \\
H-3 & C18:2 / C18:3 & $2.73: 1$ & $2.38: 1$ & $3.22: 1$ & $2.43: 1$ & $3.07: 1$ \\
& C18:1 / C18:0 & $18.46: 1$ & $10.40: 1$ & $7.75: 1$ & $3.32: 1$ & $9.07: 1$ \\
H-4 & C18:2 / C18:3 & $2.70: 1$ & $2.38: 1$ & $3.20: 1$ & $2.65: 1$ & $3.16: 1$ \\
& C18:1 / C18:0 & $17.44: 1$ & $10.55: 1$ & $7.87: 1$ & $3.12: 1$ & $8.31: 1$ \\
H-5 & C18:2 / C18:3 & $2.69: 1$ & $2.38: 1$ & $3.26: 1$ & $2.54: 1$ & $2.99: 1$ \\
& C18:1 / C18:0 & $18.83: 1$ & $10.03: 1$ & $7.46: 1$ & $2.93: 1$ & $8.46: 1$ \\
H-6 & C18:2 / C18:3 & $2.53: 1$ & $2.39: 1$ & $3.35: 1$ & $2.37: 1$ & $2.65: 1$ \\
\hline
\end{tabular}

H: Harvest, LA: Linoleic acid, LNA: Linolenic Acid, OA: Oleic Acid, SA: Stearic Acid, H: Harvest

Depending on the harvest, same genotype's oleic acid ratio was between $24.85-26.23 \%$, linoleic acid ratio was between $47.14-48.36 \%$ and linolenic acid ratio was between $19.73-20.13 \%$. When the harvest time is taken into consideration, besides linolenic acid, all the other four dominant fatty acids ratio difference was found as significant. The SFAs ratio of the $R$. canina (MR-26) was between 7.47-8.45\%, MUFAs ratio was between 24.96$30.60 \%$ and PUFAs ratio was between 61.81-66.20\%. Depending on the harvest, same genotype's oleic acid ratio was between 24.93-30.57\%, linoleic acid ratio was between $47.16-50.31 \%$ and linolenic acid ratio was 
between $14.06-15.21 \%$. When the harvest time is taken into consideration, besides palmitic acid, all the other four dominant fatty acids ratio difference was found as significant. The SFAs ratio of the $R$. dumalis ssp. boissieri (MR-46) was between 7.20-7.74\%, MUFAs ratio was between $13.15-13.81 \%$ and PUFAs ratio was between 78.66-79.46\%. Depending on the harvest, same genotype's oleic acid ratio was between $13.12-13.77 \%$, linoleic acid ratio was between $54.78-57.31 \%$ and linolenic acid ratio was between $14.06-15.21 \%$. When the harvest time is taken into consideration stearic, oleic and linolenic acids ratio difference was insignificant, while palmitic and linoleic acids ratio difference was significant. The SFAs ratio of the R. villosa (MR-84) was between $6.12-7.31 \%$, MUFAs ratio was between 21.17$24.33 \%$ and PUFAs ratio was between 68.36-72.71\%. Depending on the harvest, same genotype's oleic acid ratio was between $21.13-24.28 \%$, linoleic acid ratio was between 49.31-55.24\% and linolenic acid ratio was between 17.14-18.60 \%. Difference between harvest periods was also important from the perspective of five dominant fatty acids.

In a research carried out by Nowak (2005), total oil ratios were between $6.5 \%$ and $12.9 \%$; species with more than $10 \%$ oil content were $R$. canina var. dumalis, $R$. dumalis var. besseriana and $R$. subcanina. Kazaz et al. (2009) determined total oil ratio to be $7.15 \%$ ( $R$. canina) and $2.75 \%$ ( $R$. damascena). Çelik et al. (2010) reported that the oil ratio of wild grown different rose hip species seeds was $4.97 \%$ in $R$. canina, $5.26 \%$ in $R$. dumalis var. boissieri, $6.59 \%$ in $R$. pulverulanta, $5.44 \%$ in $R$. iberica and $7.95 \%$ in $R$. heckeliana subsp. vanheurckiana. The fatty acids content of rose hip species seeds; palmitic, palmitoleic, stearic, oleic, linoleic, linolenic and arachidic acids was between $4.25-5.15 \%, 0.22-0.89 \%, 1.80-2.43 \%$, $20.35-23.03 \%, 41.14-51.06 \%, 19.66-23.83 \%$ and $0.94-$ $1.29 \%$ respectively. On the other hand, in all the species samples SFAs was between $7.39 \%$ (R. heckeliana ssp. vanheurciana) and $8.84 \%$ (R. dumalis var. boissieri), while MUFAs+PUFAs was between $83.28 \%$ ( $R$. dumalis var. boissieri) and $91.57 \% \quad(R$. heckeliana ssp.vanheurciana); oleic, linoleic and linolenic acids were dominant in all the studied rose hip species. In another study, the oil yield of rose hip seeds belonging to different Rosa species was reported between $4.79 \%$ and $5.37 \%$. Linoleic acid $(40.5 \%)$ and linolelenic acid (16\%) were fatty acids with the highest ratio (Celik et al., 2007). Ercisli et al. (2007) reported that the seed oil of Rosa species varied between $4.60-5.37 \%$ and they determined linoleic acid $(46.31-54.03 \%), \alpha$-linolenic $(79.89 \%)$ and oleic acid $(43.81 \%)$ as dominant fatty acids. In a study conducted by Sharma et al. (2012) fatty acids composition ratio of 15 genotypes belonging to $R$. moschata, $R$. brunonii, $R$. multiflora and $R$. alba were determined to be between $45.38-54.58 \%$ (linoleic) $13.67-24.75 \%$ (linolenic) $11.97-21.08 \%$ (oleic) and $6.54-12.97 \%$ (palmitic). The researchers reported variation in linoleic and linolenic acid ratio from $1.8: 1$ to $3.4: 1$ and that oil content in different genotypes is changing between 1.3$9.0 \%$. Ilyasoglu (2013) has determined that the rose hip seed is rich with PUFAs; that linoleic and linolenic fatty acids ratio is $54.05 \%$ and $19.37 \%$ respectively; and reported that seed oil can be assessed as a plant based food source. Murathan et al. (2016) reported that some rose hip species total oil content was between $5.83 \%(R$. villosa) and $7.84 \%$ (R. dumalis) and that the total of 21 fatty acids were identified. Ercisli (2007) reported that there are nine important fatty acids in rose hips and that there are significant variations in fatty acids content between species. The researchers sorted the fatty acids form high to low ratio as linoleic, palmitic and linolenic acid respectively and pointed out that linoleic and linolenic acids are necessary in human nutrition. Similarities can be observed when our study is compared to previous ones from the perspective of total oil ratio, but significant differences in fatty acids ratio in relation to harvest are also relevant. These differences, besides species-genotype difference, are thought to have resulted from factors such as climate and soil conditions. Since there can still be no mention of standard cultivation when it comes to rose hip, it might be possible to obtain very different results and fatty acids ratios. It has been determined that monounsaturated and polyunsaturated fatty acids ratio is high in genotypes belonging to rose hip species. PUFAs ratio decreased with maturing, while MUFAs ratio increased (Figure 2-3). This situation in the late harvest period is thought to be the result of the destruction (degrading) of polyunsaturated fatty acids by oxidation with the free radicals produced enzymatically or non-enzymatically in the aging cell tissue. Also, in our opinion, the reason for the decrease of PUFAs ratio in relation to maturing is the aging of $\Delta 6$ desaturase enzyme necessary for the synthesis of the essential fatty acids (linoleic and linolenic acid). Since SFAs is not the target of the free radicals, it did not show any change in ratio in relation to the harvest.

C18:2/C18:3 ratio in $R$. canina (MR-26) was between 3.20:1 and 3.42:1; in other genotypes this ratio was between 2.37:1 and 3.22:1 in this study. It has been proven that if $\mathrm{C} 18: 2 / \mathrm{C} 18: 3$ ratio is between 2.0-3.1 it can suppress arthritis. Also, epidemiological studies determined that if this ratio is between 1.0-2.1 it has protective effect against breast and colon cancer (Artemis and Leslie, 2003). C18:1 / C18:0 ratio in R. dumalis ssp. boissieri (MR-46) was between 2.93:1 and 3.32:1; in other genotypes this ratio was between 6.20:1 and 18.83:1 (Table 2). This ratio between fatty acids is important for diagnosis of malignant tumors in prostate cancer (Wood et al., 1985). In these tumors, it enables low C18:0 and high C18:1, C18:1/C18:0 ratio change. Thus, metabolic activities ratio in tumor membrane increases (rapid transport of nutrients) and this ratio is used in determining the effect in cancer treatment. The C18:2/C18:3 and C18:1/C18:0 ratios obtained in our study are higher than the ratios determined by Sharma et al. (2012). High $\mathrm{C} 18: 2 / \mathrm{C} 18: 3$ ratio is appropriate for medical use and, consequently, the conclusion was reached that it is possible to benefit from these properties of fatty acids in all harvest periods. 


\section{Conclusion}

- Some fatty acids ratio changed significantly in relation to harvest time in rose hip accessions belonging to different species, while in some it was not.

- The conclusion was reached that in order to obtain high fatty acids ratio the appropriate harvest for $R$. canina (MR-26) would be the first or the second harvest, for $R$. dumalis (MR-12) would be the third or the fourth harvest, for $R$. dumalis (MR-15) and $R$. dumalis ssp. boissieri (MR-46) would be the fourth or the fifth harvest and for $R$. villosa (MR-84) would be the sixth harvest.

- Mono and polyunsaturated fatty acids ratios were found to be high and PUFAs ratio decreased with maturing, while MUFAs ratio increased.

- $\mathrm{C} 18: 2 / \mathrm{C} 18: 3$ ratios obtained from genotype belonging to $R$. canina were found to be remarkably high.

- A conclusion was reached that it is important to pay attention to qualitative and quantitative properties of seeds, not just plant and fruit, when conducting studies about rose hip improvement.

\section{Acknowledgement}

This study was financially supported by TUBITAK (project number: 1100668). We thank TUBITAK for its contributions.

\section{References}

Rahnavard A, Ghavamaldin A, Tavana A, Mariamalsadat T. 2013. Evaluation of biochemical compounds Rosa canina L. in North of Iran (Ramsar and Tonekabon Heights). Journal of Medicinal Plants Research 7: 3319 - 3324. DOI:10.5897/JMPR12.039 ISSN:1996-0875.

Artemis P, Leslie G. 2003. Omega-6/Omega-3 essential fatty acid ratio : The Scientific Evidence. The Center for Genetics, Nutrition and Health, Washington, D.C. USA. ISBN 3-80557640-4.

Çelik F, Balta F, Ercişli S, Kazankaya A, Javidipour I. 2010. Seed oil profiles of five rose hip species (Rosa spp.) from Hakkâri, Turkey. Journal of Food Agriculture \& Environment 8: 482 484. Print ISSN: 1459-0255 / Online ISSN: 1459-0263.

D'Amelio Franks S. 1999. Botanicals: A Phytocosmetic desk reference,1st Edition. CRC Pr I Llc, Boca Raton, Florida, U.S.A. ISBN 9781420049329.
Ercisli S. 2007. Chemical composition of fruits in some rose (Rosa spp.) species. Food Chem. 104: 1379-1384 ISSN:0308-8146.

Ercisli S, Orhan E, Esitken A. 2007. Fatty acid composition of Rosa species seeds in Turkey. Chem. Nat. Compounds 43:605-606. DOI:10.1007/s10600-007-0202-2.

Fofana B, Ghose K, Chapman B, Sanderson K. 2013. Genetic, agronomy and metabolomics of Prince Edward Island wild rose collection and promise for cultivar development. Using old solutions to new problems-natural drug discovery in the 21 st century. InTech Open Access. Doi 10.54688: 37-62. DOI: $10.5772 / 54688$.

Ilyasoglu H. 2013. Characterization of rose hip (Rosa canina L.) seed and seed oil. International Journal of Food Properties 17:1591-1598. DOI:10.1080/10942912.2013.777075.

Kazaz S, Baydar H, Erbas S. 2009. Variations in chemical compositions of Rosa damascena Mill. and Rosa canina L. fruits. Czech J. Food Sci 27: 178 - 184. ISSN : 1212-1800.

Macit M, Demirel M, Bakıcı Y, Erdoğan S. 2003. Determination of rumen degradability of Rosa canina seed by nylon-bag technique. Journal of the Faculty of Agriculture 34: 233-237. ISSN:1300-9036..

Murathan ZT, Zarifikhosroshahi M, Kafkas NE. 2016. Determination of fatty acids and volatile compounds in fruits of rose hip (Rosa L.) species by HS-SPME/GC-MS and ImSPME/GC-MS techniques. Turkish Journal of Agriculture and Forestry 40: 269 - 279. DOI:10.3906/tar-1506-50.

Nichita G, Saradan H, Padeanu I, Casaleanu I, Gogoloiu C. 1981. Eglantine (Rosa canina) seeds for feeding broiler chickens and lambs. Lucrari Stiintifice Institut Agronomic, Timisoara Zootechnie 18: 53-59.

Nowak R. 2005. Fatty acids composition in fruit of wild rose species. Acta Societatis Botanicorum Poloniae 74: 229-235. DOI: http://dx.doi.org/10.5586/asbp.2005.029.

Ozcan M. 2002. Nutrient composition of rose (Rosa canina L.) seed and oils. Journal of Medicinal Food 5: 137-140.PMID: 12495585 DOI:10.1089/10966200260398161.

Persad AR. 1990. Erythrocyte stearic to oleic acid ratio in prostatic carcinoma. British Journal of Urology 65: 268-270. PMID: 2337746.

Sharma B, Singh B, Dhyani D, Verma PK, Karthigeyan S. 2012. Fatty acid composition of wild growing rose species. Journal of Medicinal Plants Research 6: 1046-1049. DOI: 10.5897/JMPR11.1189.

Turkekul I, Yılmaz N, Şahin F, Bayrak OF. 2006. Fatty acid composition of six mushroom samples of black sea region of Turkey. Asian Journal of Chemistry 22:1479-1486. ISSN: 0975427X (Online).

Wood CB, Habib NA, Thompson A, Bradpiece H, Smadja C, Hershman M, Barker W, Apostolov K. 1985. Increase of oleic acid in erythrocytes associated with malignancies. British Medical Journal 291:163-165. PMID:3926106 PMCID:PMC1416381. 